\title{
PEMBELAJARAN DEMOKRATIS MENUJU PROFESIONALISME GURU
}

\author{
I Nengah Sudja \\ Fakultas Keguruan dan Ilmu Pendidikan \\ Universitas Mahasaraswati Denpasar
}

\begin{abstract}
Learning is the process of changing behavior as an impact obtained by the five senses that is relatively permanent. In the teaching-learning process, the teachers need a situation and condition that are supportive and condusive. At the past, the students were afraid of their teachers. They were like in a jail. Meanwhile, in the present, the teachers need to understand the surrounding and the student's chracteristics. Regarding on that notion, the teachers are expected to implement and stimulate the students with several methods of innovative teaching.
\end{abstract}

Key words: democractic, meaningful, pleased, dialogic, professional

\section{PENDAHULUAN}

Permasalahan

belajar

sebenarnya memiliki kandungan

substansi yang "misterius". Berbagai

macam teori belajar telah ditawarkan

para pakar pendidikan dengan belajar

dapat ditempuh secara efektif dan

efisien, dengan implikasi waktu cepat dan hasilnya banyak. Namun, sampai saat ini belum ada satupun teori yang dapat menawarkan strategi belajar secara tuntas.Masih banyak persoalan-persoalan belajar yang belum tersentuh oleh teori-teori tersebut.

Kompleksitas persoalan yang terkait dengan belajar inilah yang menjadi penyebab sulitnya menuntaskan strategi belajar. Ada banyak faktor yang mesti dipertimbangkan dalam belajar, baik yang bersifat internal maupun yang eksternal. Diantara sekian banyak faktor eksternal terdapat guru yang sangat berpengaruh terhadap peserta didik. Sukses tidaknya para peserta didik dalam belajar di sekolah, sebagai penyebab tergantung pada guru. Ketika berada di rumah, para peserta didik berada dalam tanggung jawab orang tua, tetapi di sekolah tanggung jawab itu diambil oleh guru. Sementara itu, masyarakat menaruh harapan yang besar agar anak-anak mengalami perubahan- 
perubahan positif-konstruktif akibat mereka berinteraksi dengan guru.

Harapan ini menjadi suatu yang niscaya terutama ketika dikaitkan dengan mutu pendidikan. Pembahasan mutu pendidikan betapapun akan terfokuskan pada input- proses-output. Input terkait dengan masyarakat sebagai “pemasok" sedangkan outuput terakait dengan masyarakat sebagai pengguna. Adapun proses terkait dengan guru sebagai pembimbing. Dataran proses inilah yang paling determinan dalam mewujudkan situasi pembelajaran di sekolah baik yang membelenggu, atau sebaliknya membebaskan, membangkitkan dan menyadarkan.

\section{PEMBAHASAN}

Proses Pembelajaran Yang

\section{Membelenggu}

Ada ungkapan yang menarik dari Emille Durkheim. Dia melukiskan dua fungsi pendidikan yang saling bertentangan yaitu pendidikan sebagai pembelenggu dan pendidikan sebagai pembebas individu. Letak daya tarik dari pernyataan ini terdapat pada fungsi pendidikan sebagai
pembelenggu.Selama ini kebanyakan masyarakat hanya memahami fungsi pendidikan sebagai pembebas individu. Ternyata pendidikan bisa berfungsi sebaliknya, sebagai pembelenggu. Hal ini memberi pemahaman berikutnya bahwa pendidikan bisa juga "berbahaya" bagi kemandirian, kreativitas dan kebebasan peserta didik sebagai individu.

Dalam kaitannya dengan fungsi negatif yakni pendidikan sebagai pembelenggu ini agaknya dapat dilacak dari model-model pembelajaran yang dilaksanakan guru di dalam kelas. Jika kita adakan evaluasi, di kalangan kita sendiri memang terdapat gejala-gejala perilaku guru dalam pembelajaran di kelas yang tidak kondusif mengakibatkan daya kritis peserta didik, bahkan dalam batas-batas tertentu membahayakan masa depan peserta didik seperti sikap guru yang sinis terhadap jawaban yang salah.

Dalam suatu kelas tidak jarang guru melemparkan suatu pertanyaan yang harus dijawab peserta didik. Ada seorang peserta didik yang berani menjawab pertanyaan dengan penuh keyakinan dan harapan 
mendapat simpati guru. Apa yang terjadi justru di luar dugaan dengan jawaban itu teman-temannya di sekitar tertawa sedang guru mengatakan, "tidak, itu salah. Saya heran melihatmu". Kasus ini menurut Bobbi Deporter and Mike Hernacki, adalah awal terbentuknya citra negatif diri. Sejak saat itu belajar menjadi tugas sangat berat.Keraguan tumbuh dalam dirinya dan dia mulai menguragi resiko sedikit demi sedikit. Sebab dia merasa malu dan dipermalukan dihadapan banyak anak, Bobbi Deporter and Mike Hernacki (2002:24). Kesan negatif ini terus membayangi dalam perkembangan lantaran komentar itu. Komentar negatif selama ini seringkali diterima anak bukan saja di sekolah, melainkan juga di rumah atau di lingkungan masyarakat. Dinding-dinding kelas dirasakan sebagai dinding-dinding tempat penjara.

Model pembelajaran berikutnya yang dapat membelenggu dan menindas peserta didik adalah sebagaimana yang Paulo Freire (2002:28) disebut sebagai pendidikan "gaya bank". Model ini menurut pengamatan Freire, menjadi sebuah kegiatan menabung: para murid sebagai celengannya sedangkan guru sebagai penabungnya. Ruang gerak yang disediakan bagi kegiatan murid hanya terbatas pada menerima, mencatat dan menyimpan. Semakin banyak murid yang meyimpan tabungan, semakin kurang mengembangkan kesadaran kritisnya.

Sesungguhnya, belajar itu merupakan pekerjaan yang cukup berat, yang menuntut sikap kritis sistemik (Sistemic Critical Attitude) dan kemampuan intelektual yang hanya dapat diperoleh dengan praktek langsung. Sikap kritis sama sekali tidak dapat dihasilkan melalui pendidikan yang bergaya bank (banking action) ini. Dalam pendidikan model ini, yang dibutuhkan buka pemahaman isi, tetapi sekedar hafal (memorization). Bukan memahami teks, tetapi hanya menghafal dan jika peserta didik melakukannya berarti peserta didik telah memenuhi kewajibannya; Padahal hafalan hanya akan menumpuk pengetahuan dalam arti pasif, karena tanpa upaya pengembangan sama sekali sebagai yang menjadi karakternya selama ini. 
Selanjutnya, pembelajaran model bank ini telah menempatkan guru dan peserta didik dalam posisi berhadap-hadapan. Guru sebagai subyek dan peserta didik sebagai obyek, guru yang "menakdirkan" sedangkan peserta didik yang "ditakdirkan", guru sebagai peran dan siwa sebagai yang diperankan. Secara ekstrim bahkan dapat dikatakan guru sebagai penindas sedang peserta didik sebagai tertindas. Freire setidaknya telah mengungkapkan peran yang kontras itu sebagai berikut: (1) guru mengajar, murid diajar, (2) guru mengethui segala sesuatu, murid tidak tahu apa-apa, (3) guru berfikir, murid dipikirkan, (3) guru bercerita, murid patuh mendengarkan, (4) guru menentukan peraturan, murid diatur, (5) guru memilih dan memaksakan pilihannya, murid menyetujuinya, (6) guru berbuat, murid membayangkan dirinya berbuat melaui perbuatan gurunya, (7) guru memiliki bahan dan isi pelajaran, murid menyesuaikan diri dengan pelajaran itu, (8) guru mencampur adukkan kewenangan ilmu pengetahuan dan kewenangan jabatannya, yang ia lakukan untuk menghalangi kebebasan murid, (9) guru adalah subyek dalam proses belajar, murid adalah obyek belaka, (Nasution, 1999:116).

Pengajaran model demikian ini memposisikan guru sebagai pihak yang "menang" sedangkan peserta didik sebagai pihak yang "kalah", suatu dikotomi yang mestinya tidak layak terjadi mengingat pengajaran bukan proses perbandingan sehingga ada yang menang dan ada yang kalah. Dengan istilah lain pengajar ini terkadang disebut pengajaran model komando. Seorang komandan dalam militer posisinya selalu diatas, memegang perintah yang harus ditaati.

Pengajaran model gaya komando ini memerankan guru, yang oleh S. Nasution (1999:116) disebut guru yang bertipe dominatif sebagai lawan dari tipe integrative. Pengajaran tersebut mendapat kritik keras karena mematikan semangat demokratisasi dan kreativitas peserta didik, tidak menghargai peserta didik dan keragamannya. Guru merasa memiliki wewenang apa saja yang berkaitan dengan pembelajaran dan tidak boleh diganggu gugat oleh peserta didik maupun pihak lain, 
praktis, pengajaran model tersebut hanya menjadikan guru pandai sepihak sedangkan peserta didik tetap bodoh, pasif, kering ide atau gagasan, stagnan, tertindas dan terbelenggu.

Upaya pembelajaran yang ternyata berbalik membelenggu ini tidak lepas begitu saja, karena akibat demikian tidak pernah disadari guru dominatif tersebut, selagi belum ada gugatan secara maksimal untuk mewujudkan pembelajaran yang benar-benar demokratis sebagai kebutuhan pendidikan secara mendesak.

\section{Pembelajaran Demokratis}

Sebagai upaya untuk keluar dari pembelajaran yang bersifat membelenggu tersebut menuju pada pembelajaran yang membebaskan dibutuhkan keterbukaan dan sikap lapang dada dari guru untuk memberikan kesempatan seluasluasnya kepada peserta didik guna mengekspresikan gagasan dan pikirannya. Freire mengatakan, pendekatan yang membebaskan merupakan proses dimana pendidikan mengkondisikan peserta didik untuk mengenal dan mengungkapkan kehidupan yang nyata secara kritis." Dalam pendidikan yang membebaskan ini tidak ada subjek yang membebaskan atau objek yang dibebaskan karena tidak ada dikotomi antara subjek dan objek. Guru dan peserta didik samasama subjek dan objek sekaligus. Keduanya dimungkinkan saling take and give (menerima dan memberi). Hanya saja jika guru sebagai pembelajar senior, maka peserta didik sebagai pembelajar junior, ,jadi tetap ada perbedaan pengalaman dan karena perbedaan inilah sehingga guru tetap lebih banyak memberi kepada peserta didik dari pada peserta didik memberi kepada guru. Tetapi pemberian guru kepada peserta didik itu sifatnya dorongan, rangsangan atau pancingan agar peserta didik berkreasi sendiri, bukan sebagai stimulus.

Aliran ini sesungguhnya telah berpandangan progresif. Peran peserta didik telah dimaksimalkan jauh melebihi peran-peran tradisionalnya dalam himpitan pengajaran model gaya komando. Upaya memaksimalkan peran peserta didik ini sebagai bentuk riil dari misi pembebasan peserta didik dari 
keterbelengguan akibat penindasan guru. Melalui pembebasan ini, diharapkan peserta didik memiliki kemandirian yang tinggi dalam memberdyakan potensi yang dimiliki untuk berpendapat, bersikap dan berkreasi sendiri. Oleh karena itu, mesti ada dialog. Ciri aksi budaya yang meperjuangkan kebebasan adalah dialog, sedangkan yang mengarah pada dominasi justru anti dialog. Tangung jawab guru yang menempatkan diri teman dialog bagi peserta didik lebih besar dari pada guru yang hanya memindahkan informasi yang harus diingat peserta didik; Sebab guru sedang memupuk sikap keberanian, sikap kritis ,dan sikap toleran terhadap pandangan yang berbeda bahkan bertentangan sekalipun, melalui tradisi saling tukar pandangan dalam menyiapkan suatu masalah.

Tradisi dialogis ini sebagai salah satu bentuk suasana yang mendukung pembelajaran demokratis, yaitu suasana yang melibatkan para peserta didik dalam proses pembelajaran secara maksimal dengan memperhatikan sepenuhnya terhadap inisiatif, pemikiran, gagasan, ide, kreativitas, dan karya peserta didik. Mereka diberikan kesempatan seluas-luasnya untuk menjadi subjek dalam proses pembelajaran.

Mengingat pentingnya dialog ini, maka pemerintah mengamanatkan melalui Undangundang Sistem Pendidikan Nasional yang ditetapkan sebagai kewajiban yang harus dipenuhi oleh pendidik dan tenaga kependidikan. Amanat itu terdapat pada pasal 40 ayat 2. Isi dari pasal tersebut adalah pendidik dan tenaga kependidikan berkewajiban: menciptakan suasana pendidikan yang bermakna, menyenangkan, kreatif, dinamis dan dialogis; mempunyai komitmen secara professional untuk meningkatkan mutu pendidikan, dan memberikan teladan serta menjaga nama baik lembaga, profesi, dan kedudukan sesuai dengan kepercayaan yang diberikan kepadanya.

Seiring dengan demokrasi politik. Ada tuntutan demokrasi pendidikan dalam prakteknya berimplikasi pada demokrasi pembelajaran dengan indikasi menciptakan suasana dialogis. Dengan demikian, peranan guru dalam penyampaian pengetahuan 
menjadi sangat berkurang yang digantikan oleh peranan peserta didik yang semakin menguat. Tuntutan dialog belakangan ini sebagai suatu yang tak terelakkan lagi dalam kehidupan pendidikan demokratis, sekaligus membuktikkan adanya pergeseran posisi peserta didik dari posisi objek ke posisi subjek dalam berbagai kesempatan. Demikian pula, pergantian istilah anak didik, terdidik maupun objek didik menjadi peserta didik bahkan pembelajar bukan hanya persoalan semantik, melainkan perubahan paradigma pembelajaran yang banyak dipengaruhi oleh aliran-aliran pendidikan yang berorientasi pada kondisi demokratis dan emansipatoris, dengan memerankan peserta didik agar lebih produktif,progresif dan pro-aktif dibandingkan peran masa lampaunya. Bagaimana istilah peserta didik apalagi pembelajar akan selalu mengesankan kondisi aktif pada anak didik, terdidik maupun objek didik; oleh karena itu, belakangan ini pengertian perencananaan untuk memberi peluang pada peserta didik-peserta didiknya mengembangkan aktivitas belajar, serta mengeksplorasi berbagai pengalaman baru untuk mencapai berbagai kompetensi yang diidealkannya, dan telah menjadi kesepakatan-kesepakatan kelas bersama dengan gurunya. Guru tidak banyak mencampuri mengatur dan menegur pekerjaan anak, akan tetapi membiarkan bekerja menurut kemampuan dan cara masing-masing sikap, hal inisesuai dengan sistem pembelajaran student centered.

Selanjutnya, perkembangan paling menarik terjadi sejak 25 tahun terakhir bahwa guru-guru di berbagai sekolah di Amerika melakukan transaksi kurikulum dengan para peserta didiknya. Guru menawarkan berbagai kompetensi pada peserta didiknya, sedang peserta didik memilih serta menentukan sendiri apa yang mereka pelajari dengan gurunya itu. Implikasinya adalah terjadi kajian dari sesama peserta didik untuk menentukan berbagai bahan materi pelajaran yang akanmereka pelajari dalam masa tertentu. Inilah yang disebut sebagai curriculum as transaction and curriculum as inquiry.

Kasus ini benar-benar menggambarkan pembelajaran 
demokratis lantaran melibatkan peserta didik dalam menentukan sendiri kompetensi maupun bahan pelajaran sesuai dengan selera dan kebutuhan mereka sendiri tanpa paksaan maupun intervensi guru. Keterlibatan peserta didik seperti ini makin mendesak untuk direalisasikan, sehingga dibutuhkan guru yang benar-benar profesional.

\section{Profesionalisme Guru}

Suatu profesionalisme akan menjadi taruhan ketika mengahadapi tuntutan-tuntutan pembelajaran demokratis karena tuntutan tersebut merefleksikan suatu kebutuhan yang semakin kompleks yang berasal dari peserta didik; tidak sekedar kemampuan guru menguasai materi pelajaran semata tetapi juga kemampuan lainnya yang bersifat psikhis, strategis dan produktif. Tuntutan demikian ini hanya bisa dijawab oleh guru yang professional. Oleh karena itu, Sudarwan Danim (2003:192) menegaskan bahwa tuntutan kehadiran guru yang profesional tidak pernah surut, karena dalam proses kemanusiaan dan pemanusiaan, ia hadir sebagai subjek paling diandalkan, yang sering kali disebut sebagai Oemar bakri.

Istilah professional berasal dari profession, yang mengandung arti sama dengan occupation atau pekerjaan yang memerlukan keahlian yang diperoleh melalui pendidikan atau latihan khusus. Ada beberapa pengertian yang berkaitan dengan professionalisme yaitu okupasi, profesi dan amative, maka para profesional adalah para ahli di dalam bidangnya yang telah memperoleh pendidikan atau pelatihan dan ketrampilan yang khusus untuk pekerjaan itu.

Berbicara masalah profesional tidak bisa lepas dengan kompetensi; M. Arifin (1991:105) menegaskan bahwa kompetensi itu bercirikan tiga kemampuan profesional yakni kepribadian guru, penguasaan ilmu dan bahan pelajaran, serta ketrampilan mengajar yang disebut the teaching triad. Hal ini berarti antara profesi dan kompetensi memilki hubungan yang erat: profesi tanpa kompetensi akan kehilangan makna, dan kopetensi tanpa profesi akan kehilangan guna.

Guna memahami profesi, kita harus mengenali melalui ciri- 
cirinya.Adapun ciri-ciri dari suatu profesi adalah: (1) memiliki suatu keahlian khusus; (2) merupakan suatu penggilan hidup; (3) memiliki teori-teori yang baku secara universal; (4) mengabdikan diri untuk masyarakat dan bukan untuk diri sendiri; (5) dilengkapi dengan kecakapan diagnostik serta kompetensi yang aplikatif; (6) memiliki otonomi dalam melaksanakan pekerjaannya; (7) mempunyai kode etik;

mempunyai klien yang jelas; (9) mempunyai organisasi profesi yang kuat; (10) mempunyai hubungan dengan profesi pada bidang-bidang yang lain. Sudja (2013:20) menyebutkan karakteristik profesional minimum guru berdasarkan temuan-temuan hasil adalah: (1) mempunyai komitmen pada siswa dan prses belajarnya, (2) menguasai secara mendalam bahan belajar atau mata pelajaran serta cara pembelajarannya; (3) bertanggung jawab memantau hasil belajar peserta didik melalui berbagai cara evaluas; (4) mampu berfikir sistematis tentang apa yang dilkukannya dan belajar dari pengalamannya; (5) mampu menjadi partisipan aktif masyarakat belajar dalam lingkungan prfesinya.

Ciri-ciri tersebut masih umum, karena belum dikaitkan dengan bidang keahlian tertentu. Bagi profesi guru berarti ciri-ciri itu lebih spesifik lagi dalam kaitannya dengan tugas-tugas pendidikan dan pengajaran baik di dalam maupun di luar kelas.

Mengenai kompetensi, di Indonesia telah ditetapkan sepuluh kompetensi yang harus dimiliki oleh guru sebagai instructional leader, yaitu: (1) memiliki kepribadian ideal sebagai guru; (2) penguasaan landasan pendidikan; (3) menguasai bahan pengajaran; (4) kemampuan menyusun program pengajaran; (6) kemampuan menilai hasil dan proses belajar mengajar; (7) kemampuan menyelenggarakan program bimbingan; (8) kemampuan menyelenggarakan administrasi sekolah; (9) kemampuan bekerja sama dengan teman sejawat dan masyarakat; dan (10) kemampuan menyelenggarakan penelitian sederhana untuk keperluan pengajaran. Selanjutnya, dalam pasal 8 ayat 3 UU RI No. 14 Tahun 2005 disebutkan kompetensi sebagai agen 
pembelajaran pada jenjang pendidikan dasar dan menengah serta pendidikan anak usia dini meliputi:

(1) kompetensi pedagogik, (b) kompetensi kepribadian, (c) kompetensi professional, dan kompetensi sosial.

Dengan demikian, tugas guru menjadi lebih luas lagi dari pada proses mentranformasikan pengetahuan, membangun afeksi, dan mengembangkan fungi psikomotorik, karena di dalamnya terkandung fungsi-fungsi produksi. Guru yang mogok mengajar apapun alasannya merupakan counter productive proses pendidikan dan pembelajaran yang bermisi kemanusiaan universal itu. Dari sisi etika keguruan juga tidak layak terjadi sebab figur guru menjadi panutan di kalangan masyarakat setidaknya bagi para peserta didiknya sendiri. Di sini predikat guru sebagai pendidikitu berkonotasi dengan tindakan-tindakan yang senantiasa memberi contoh yang baik dalam semua perilakunya.

Sebagai pendidik, guru harus profesional sebagaimana ditetapkan dalam Undang-undang Sitem Pendiidkan Nasional bab IX pasal 39 ayat 2: Pendidik merupakan tenaga profesional yang bertugas merencanakan dan melaksanakan proses pembelajaran, menilai hasil pembelajaran, melakukan pembimbingan dan pelatihan, serta melakukan penelitian dan pengabdian kepada mayarakat, terutama bagi pendidikan di perguruan tinggi.

Ketentuan ini mencakup tipe macam kegiatan yang harus dilaksanakan oeh guru yaitu pengajaran, penelitan, dan pengabdian masyarakat.Beban ini tidak ada bedanya denganbeban bagi dosen. Tiga macam kegiatan tersebut secara khierarchy melambangkan tiga upaya berjenjang dan meluas gerakannya.

Pengajaran melambangkan pelaksanaan tugas rutin, penelitian melambangkan upaya pengembangan profesi, sedang pengabdian melambangkan pemberian kontribusi sosial kepada masyarakat akibat prestasi yang dicapai tersebut.

Dari ketiga kegiatan tersebut, terutama penelitian menuntut sikap guru dinamis sebagai seorang profesional. Seorang profesional adalah seorang yang terus 
menerusberkembang atau trainable. Untuk mewujudkan keadaan dinamis ini pendidikan guru harus mampu membekali kemampuan kreativitas, rasionalitas, keterlatihan memecahkan masalah, dan kematangan emosionalnya. Semua bekal ini dimaksudkan mewujudkan guru yang berkualitas sebagai tenaga profesional yang sukses dalam menjalankan tugasnya.

Keberhasilan guru dapat ditinjau dari dua segi proses dan dari segi hasil. Dari segi proses, guru berhasil bila mampu melibatkan sebagian besar peserta didik secara aktif baik fisik, mental maupun sosial dalam proses pembelajaran, juga dari gairah dan semangat mengajarnya serta adanya rasa percaya diri. Sedangkan dari segi hasil, guru berhasil bila pembelajaran yang diberikannya mampu mengubah perilaku pada sebagian besar peserta didik ke arah yang lebih baik. Sebaliknya,dari sisi peserta didik, belajar akan berhasil bila memenuhi tiga persyaratan: (1) belajar merupakan sebuah kebutuhan peserta didik, dan (2)ada kesiapan untuk belajar, yakni kesiapan memperoleh pengalaman- pengalaman baru baik pengetahuan maupun ketrampilan, (3) adanya perubahan perilaku yang dimilikinya.

Hal ini merupakan gerakan dua arah, yaitu gerakan profesional dari guru dan gerakan emosional dari peserta didik. Apabila yang bergerak hanya satu pihak tentu tidak akan berhasil, yang dalam istilah seharihari disebut bertepuk sebelah tangan. Sehebat-hebatnya potensi guru selagi tidak direspons positif oleh peserta didik, pasti tidak berarti apa-apa. Jadi gerakan dua arah dalam mensukseskan pembelajaran antara guru dan peserta didik itu sebagai gerakan sinergis.

Bagi guru yang profesioanl, dia harus memiliki kriteria-kriteria tertentu yang positif. Gilbert H. Hunt menyatakan bahwa guru yang baik itu harus memenuhi tujuh kriteria: (1) sifat positif dalam membimbing peserta didik, (2) pengetahuan yang mamadai dalam mata pelajaran yang dibina, (3) mampu menyampaikan materi pelajaran secara lengkap, (4) mampu menguasai metodologi pembelajaran, (5) mampu memberikan harapan riil terhadap peserta didik, (6) mampu mereaksi 
kebutuhan peserta didik, (7) mampu menguasi manajemen kelas.

Disamping itu, ada satu hal yang perlu mendapatkan perhatian khusus bagi guru yang profesional yaitu kondisi nyaman lingkungan belajar yang baik secara fisik maupun psikis. Undang-undang Sistem Pendidikan Nasional pasal 40 ayat 2 bagian 2 di muka menyebut dengan istilah menyenangkan. Demikian juga E. Mulyasa (2002:187) menegaskan, bahwa tugas guru yang paling utama adalah bagaimana mengkondisikan lingkungan belajar yang menyenangkan, agar dapat membangkitkan rasa ingin tahu semua peserta didik sehingga timbul minat dan nafsunya untuk belajar. Adapun Bobbi Deporter dan Mike Hernachi (2002:24) menyarankan agar memasukkan musik dan estetika dalam pengalaman belajar peserta didik, karena musik berhubungan dan mempengaruhi kondisi fisiologis peserta didik yang diiringi musik membuat pikiran selalu siap dan mampu berkonsentrasi.dalam situasi otak kiri sedang bekerja, masuk akan membangkitkan reaksi otak kanan yang intuitif dan kreatif sehingga masukannya dapat dipadukan dengan keseluruhan proses belajar.

Terkait dengan suasana yang nyaman ini, perlu dipikirkan oleh guru yang profesional yaitu menciptakan situasi pembelajaran yang bisa menumbuhkan kesan hiburan. Mungkin semua peserta didik menyukai hiburan, tetapi mayoritas mereka jenuh dengan belajar. Bagi mereka belajar adalah membosankan, menjenuhkan, dan di dalam kelas seperti di dalam penjara. Dari evaluasi yang didasarkan pada pengamatan ini, maka sangat dibutuhkan adanya proses pembelajaran yang bernuansa menghibur. Nuansa pembelajaran ini menjadi “pekerjaan rumah"bagi para guru khususnya guru yang profesional.

\section{SIMPULAN}

Pembelajaran yang demokratis yang membawa misi pembebasan bagi peserta didik untuk mewujudkan model pendidikan yang emansipatoris itu dibutuhkan guru yang professional, yakni guru yang mencerminkan berbagai keahlian yang dibutuhkan pembelajaran baik terkait dengan bidang keilmuan yang 
diajarkan,"kepribadian", metodologi, pembelajaran, maupun psikologi belajar.

\section{DAFTAR PUSTAKA}

Aldridge, J And Renetta Soldman. (2002) Current issues and trends in education. Boston. USA: Allya And Baron.

Arifin, M. (1991). Kapita selekta pendidikan islam dan umum. Jakarta: Bumi Aksara.

Bobbi, D. dan Mieke Hernachi. (2002). Quantum learning membiasakan belajar nyaman dan menyenangkan. Bandung: Kaifa.

Djohar. (2003). Pendidikan strategik alternatif untuk pendidikan masa depan. Yogyakarta: LESFI.

Donald, P. Kauchosck And Paul D. Eggen. (1998). Learning and teaching research basid methods. baston: Allya And Baron.

Freire, P. (2002). Politik pendidikan dan kebudayaan, kekuasaan dan pembebasan. Yogyakarta: Kerjasama Pustaka Pelajar dengan ead.

Kuntoro, A. (1985). Dimensi manusia dalam pemikiran indonesia. Yogyakarta: CV Bur Cahaya.

Masstlon, M. (1972). Tracking from command to discovery. California: Wadsworth Publishing Company.
Mulyasa, E. (2005). Menjadi kepala sekolah profesional. Bandung: PT. Remaja Rosda Karya.

Nasution, S. (1999). Sosiologi Pendidikan. Jakarta: Bumi Aksara.

Rosyada, D. (2004). Paradigma pendidikan demokratissebuah pelibatan masyarakat dalam penyelenggaraan pendidikan. Jakarta: Prenada Media.

Sudarwan, D. (2003) Agenda pemabruan sistem pendidikan. Yogyakarta: Pustaka Pelajar.

Sudja, N. (2013). Pengaruh kompetensi, kepemimpinan diri, sistem penghargaan, lingkungan kerja terhadap komitmen pada profesi dan profesionalisme guru (Disertasi). Surabaya: Pascasarjana Untag Surabaya.

Tilaar, H. A. R. (2000). Paradigma baru pendidikannasional. Jakarta: PT Rineka Cipta.

Undang-undang republik indonesia nomor 14 tahun 2005 tentang guru dan dosen. Jakarta: Tamita Utama.

Undang-undang republik indonesia nomor 20 tahun 2003 tentang sistem pendidikan nasional. Ttp: Pustaka Widyatama, Tt. 